\title{
Characteristics of Cervical Precancerous Lesions at a Tertiary Hospital in Bali, Indonesia
}

\author{
I Nyoman Gede Budiana*1, Ida Bagus Rendra Kurniawan Artha ${ }^{2}$ \\ ${ }^{1}$ Division of Gynecologic Oncology, Department of Obstetrics and Gynecology, Faculty of Medicine Udayana University/ \\ Sanglah Hospital, Denpasar, Bali, Indonesia \\ ${ }^{2}$ Department of Obstetrics and Gynecology, Faculty of Medicine Udayana University/Sanglah Hospital, Denpasar, Bali, Indonesia
}

\section{ARTICLE INFO}

Received : 06 April 2020

Reviewed : 04 June 2020

Accepted : 02 November 2020

Keywords:

Bali, cervical precancerous lesion, characteristics, tertiary hospital

\author{
*Corresponding author: \\ I Nyoman Gede Budiana \\ Division of Gynecologic Oncology, \\ Department of Obstetrics and \\ Gynecology, Faculty of Medicine \\ Udayana University/Sanglah Hospital, \\ Denpasar, Bali, Indonesia \\ william.alexanders11@gmail.com
}

\begin{abstract}
Background: Cervical cancer is one of the biggest women's health issues in developing countries including Indonesia. This study is aimed to describe the characteristics of cervical precancerous lesions at a tertiary hospital in Bali, Indonesia.
\end{abstract}

\begin{abstract}
Methods: This is a descriptive study using data from the medical records of patients with precancerous cervical lesions who attended the Gynecologic Oncology Outpatient Clinic Sanglah Hospital Denpasar, Bali, Indonesia, from January to December 2017.
\end{abstract}

\begin{abstract}
Results: There were 276 cases $(2.88 \%)$ of the cervical precancerous lesion during the study period. The majority of cases were diagnosed within the age group of $36-45$ years (37.7\%), had low education levels $(42.7 \%)$, obese (53.5\%), multiparous (73.9\%), had first sexual intercourse at the age of $16-20$ years (41.3\%), had used IUD as a contraceptive method (41.4\%), and had a cytologic diagnosis of atypical squamous cells of undetermined significance (ASC-US) that preceded the histologic diagnosis (43.2\%). The most common histologic diagnosis was CIN I (43.1\%) and the most common treatment was cryotherapy (56.2\%).
\end{abstract}

Conclusions: The majority of cervical precancerous lesion cases were diagnosed among women who were between her third and fourth decade of life, had low education level, were obese, multiparous, had a sexual debut at a younger age, and were IUD users. The majority of cases were low-grade lesions.

\section{INTRODUCTION}

Cervical cancer is a malignant disease in the uterine cervix. Cervical cancer develops from precancerous lesions characterized by dysplastic changes in the cervical epithelium. The diagnosis of cervical cancer is not difficult, especially if it has been found at an advanced stage. One of the factors that support the successful management of cervical cancer is the effort to find cases in the precancerous phase and early stages of cervical cancer and to treat them appropriately [1]. The finding and proper management at an early stage will provide better treatment results so that death from cervical cancer can be avoided. Up to now, cervical cancer is still a women's health issue in developing countries including Indonesia, due to its high incidence and mortality rate [2]. According to the Indonesian Ministry of Health in 2010, the incidence of cervical cancer is 100 in 100,000 population in a year, and this number is expected to continue to increase by $25 \%$ in the next 10 years if preventive measures are not taken [3].
Cervical precancerous lesions are preceded by HPV infection and influenced by several factors that increase the risk of precancerous lesions including old age, too early marital age, too many sexual partners, sexually transmitted diseases, multiparity, the use of contraception, smoking, and low socioeconomic status [4]. These risk factors will play a role in the process of carcinogenesis, thus changing normal cells into abnormal cells that lead to cervical cancer [1]. This study is aimed to describe the characteristics of cervical precancerous lesions at a tertiary hospital in Bali, Indonesia.

\section{METHODS}

This study was a descriptive study conducted at Sanglah Hospital Denpasar from January to December 2017. All women diagnosed with cervical precancerous lesions who attended the Gynecologic Oncology Outpatient Clinic, Obstetrics and Gynecology Department, Sanglah Hospital Denpasar during the study period were 
recruited into the study population. A cervical precancerous lesion was diagnosed from histopathology examination of the cervical biopsy specimen. Data about the sociodemographics and the clinical characteristics of the study population were extracted from the patient's medical record. Inclusion criteria were new cases of cervical precancerous lesions and having complete clinical and sociodemographic data on medical records. The exclusion criterion was incomplete medical records. Ethical approval and research permission were obtained from the hospital ethics committee of the Medical Faculty of Udayana University with registration number 2498/ UN.14.2/KEP/2017. The data obtained were then collected, processed, and presented in table and narrative form.

\section{RESULTS}

\section{Sociodemographics of The Study Population}

During the study period, there were 276 cases of cervical precancerous lesions diagnosed. The sociodemographics of the study population were summarized in Table 1 . The majority of cases were diagnosed within the third and fourth decades of life. They were also multiparous, had a low educational level, and normal BMI. Regarding sexual behavior, the majority had first sexual intercourse at a younger age (16-20 years) and used IUD as contraception.

\section{Distribution of cervical precancerous lesions}

The distribution of cervical precancerous lesions in this study was as follow: 56 (20.2\%) cases of low grade squamous intraepithelial lesions (LSIL), 48 (17.4\%) cases of high grade squamous intraepithelial lesions (HSIL), 119 (43.2\%) cases of atypical squamous cells of unknown significance (ASC-US), and 53 (19.2\%) cases of atypical squamous cells of unknown significance-cannot exclude high-grade lesion (ASC-H). Two hundred twenty five patients performed biopsy and histopathology examination. While 51 patients underwent cryotherapy and no histopathology examination was performed. Of the 225 patients who underwent histopathology examination, there were 96 patients with chronic cervicitis, 6 patients with cervical cancer ( 4 patients with NKSCC and 2 patients with adenocarcinoma) were later excluded from this study. Therefore, the total number of patients with cervical precancerous lesions based on histopathology results were 123 patients (Table 2).

\section{Type of treatment}

Table 3 summarizes the type of treatment received by the study population. A total of 180 patients were treated, while 96 patients with chronic cervicitis were given medical management. The majority of cases underwent cryotherapy.
Table 1. Sociodemographic characteristics

\begin{tabular}{|c|c|c|}
\hline Characteristics & $\begin{array}{c}\text { Total } \\
(n=276)\end{array}$ & $\begin{array}{c}\text { Percentage } \\
\text { (\%) }\end{array}$ \\
\hline \multicolumn{3}{|l|}{ Age } \\
\hline $16-25$ years old & 11 & 3.9 \\
\hline 26-35 years old & 63 & 22.8 \\
\hline $36-45$ years old & 104 & 37.7 \\
\hline $46-55$ years old & 71 & 25.8 \\
\hline$\geq 56$ years old & 27 & 9.8 \\
\hline \multicolumn{3}{|l|}{ Educational Level } \\
\hline Primary education level & 118 & 42.7 \\
\hline Secondary education level & 86 & 31.1 \\
\hline Tertiary education level & 72 & 26.1 \\
\hline \multicolumn{3}{|l|}{ Body Mass Index (BMI) } \\
\hline Underweight $(<18,5 \mathrm{~kg} / \mathrm{m} 2)$ & 34 & 12.4 \\
\hline Normal $(18,5-24,9 \mathrm{~kg} / \mathrm{m} 2)$ & 94 & 34.1 \\
\hline $\begin{array}{l}\text { Overweight/Obese } \\
\left(25,0-34,9 \mathrm{~kg} / \mathrm{m}^{2}\right)\end{array}$ & 148 & 53.5 \\
\hline \multicolumn{3}{|l|}{ Number of parity } \\
\hline Nulliparity & 31 & 11.3 \\
\hline Primiparity & 41 & 14.8 \\
\hline Multiparity & 204 & 73.9 \\
\hline \multicolumn{3}{|l|}{$\begin{array}{l}\text { Age of first time having sexual } \\
\text { intercourse }\end{array}$} \\
\hline 16-20 years old & 114 & 41.3 \\
\hline $21-25$ years old & 65 & 23.6 \\
\hline 26-30 years old & 59 & 21.4 \\
\hline 31-35 years old & 38 & 13.7 \\
\hline \multicolumn{3}{|l|}{ Contraceptive method } \\
\hline Non & 47 & 17.1 \\
\hline Pills & 38 & 13.8 \\
\hline Injection & 57 & 20.6 \\
\hline Implant & 9 & 3.2 \\
\hline IUD & 114 & 41.4 \\
\hline Sterile & 11 & 3.9 \\
\hline
\end{tabular}

Table 2. Classification of cervical precancerous lesion

\begin{tabular}{lcc}
\hline Classification & Total & Percentage (\%) \\
\hline $\begin{array}{l}\text { Histopathology } \\
\quad \text { Cervical Intraepithelial } \\
\quad \text { Neoplasia grade I }\end{array}$ & 53 & 43.1 \\
$\quad \begin{array}{l}\text { Cervical Intraepithelial } \\
\text { Neoplasia grade II }\end{array}$ & 42 & 34.1 \\
$\quad \begin{array}{l}\text { Cervical Intraepithelial } \\
\text { Neoplasia grade III }\end{array}$ & 28 & 22.8 \\
Total & 123 & 100 \\
\hline
\end{tabular}

Table 3. Type of treatment for cervical precancerous lesion

\begin{tabular}{ccc}
\hline Treatment & Total & Percentage (\%) \\
\hline Monitoring & 41 & 22.7 \\
Cryotherapy & 101 & 56.2 \\
LEEP/LLETZ & 27 & 15.0 \\
Hysterectomy & 11 & 6.1 \\
Total & $\mathbf{1 8 0}$ & $\mathbf{1 0 0}$ \\
\hline
\end{tabular}

LEEP/LLETZ, loop electrosurgical excision procedure/large loop excision of the transformation zone 


\section{DISCUSSION}

In this study, we found that the majority of cervical precancerous lesions were diagnosed within the third and fourth decade of life. Similar observations had been reported from studies conducted in developing countries. In studies by Okwi [5] and Makuza et al. [6] in Africa and a study by Das et al. [7] in South Asia, they reported that cervical precancerous lesions were most prevalent between the third and fourth decade of life

Regarding sexual behavior, the majority of our study population had their first sexual intercourse at a younger age (16-20 years). Similar results were obtained in the studies by Okwi [5], Das et al. [7], and Utoo et al. [8] who reported a higher prevalence of precancerous lesions in the group of subjects who had their first sexual intercourse at the age younger than 20 years. Young age at sexual debut has been associated with an increased risk of contracting HPV infection [9]. This vulnerable period is related to the process of metaplasia at puberty. Factors that can interfere with the metaplastic changes, such as infection, can potentially trigger dysplasia and subsequent carcinogenesis [10]. On the other hand, in young women, the squamocolumnar junction (SCJ) is located outside of the external uterine ostium. Therefore, the SCJ of young women is susceptible to external factors, such as mutagens that can trigger dysplastic changes of the epithelium.

Most of our study population had a low educational level. A similar observation has been reported in a study by Makuza et al. [6] and Teame et al. [11], in which the highest prevalence of precancerous lesions was found in a group of patients with a low educational level. The low socioeconomic level has been described as a risk factor for cervical carcinogenesis [7]. A person's educational level can support or influence his/her level of knowledge and a low level of education is always associated with limited information and knowledge. Low education will also cause barriers to access to health centers [12].

More than half of our study population were obese. Lertcharernrit et al. [13] conducted a study in Thailand and reported that the most positive IVA results were found in the obese subjects group (46.4\%), followed by normal and overweight (32.1\%), and the lowest in the thin group (21.4\%). Meanwhile, the highest positive pap smear test results were in the normal weight and obese group (60.4\%), followed by the thin (32.0\%), and obese group (28.0\%). The mechanism associated with excess body weight and increased risk of cancer is that fat tissue increases insulin and insulin levels such as Growth Factor-1 (IGF1) which favors tumor progression. Fat cells may also have direct and indirect effects on the growth of tumor regulators, including mammalian rapamycin (mTOR), and AMP (protein kinase activity).

We found that cervical precancerous lesions were the most prevalent in the multipara group (73.9\%). Similar results were observed in studies by Okwi [5],
Teame et al. [11], and Lertcharernrit e al. [13], which found that the majority of subjects with precancerous lesions had a history of multiparity. High parity has been known to increase the risk of cervical squamous cell carcinoma among women with HPV infection [7].

The majority of our study population had used IUD as a contraceptive method. It has been shown that hormonal contraception and IUD are risk factors for cervical precancerous lesions. Oral contraceptive pills are thought to cause folic acid deficiency, which reduces mutagen metabolism, while estrogen is likely to be one of the co-factors that can make HPV DNA replication [14]. According to Andrijono [3], the use of hormonal contraception increases the risk of cervical cancer. The use of 10-year hormonal contraception increases the risk twice. A meta-analysis study by Cortessis (2017) stated that the relationship between IUD users and the incidence of cervical cancer reached $30 \%$ [15]. The layers underlying the transformation zone are manipulated during IUD insertion and are at risk of causing cell-mediated immune responses that can cause cervical precancerous cervical lesions. The long-term immune response from the insertion of an IUD induces small local foci in the endocervix and cervix which will cause local mucosal changes towards the cervical precancerous lesions.

In this study, atypical squamous cells of undetermined significance (ASC-US) was the most prevalent cytologic abnormality (43.2\%), followed by the low-grade squamous intraepithelial lesion (LSIL) (20.2\%), atypical squamous cells, cannot exclude HSIL (ASC-H) (19.2\%), and lastly high-grade squamous intraepithelial lesion (HSIL) (17.4\%). Patients with low-grade lesions will generally return to ASC-US and eventually return to normal without treatment, with an average regression time of 7.8 months for low-risk-type HPV and 13.8 months for high-risk-type HPV. Most lowgrade lesions can disappear without treatment, especially if they occur in young women, and it is estimated that, of 1 million infected women, only $10 \%$ will develop cervical precancerous lesions. The progression from high-grade lesions to cervical cancer generally occurs after $10-20$ years. There are $50 \%$ of 557 women with dysplasia, turning into carcinoma in situ with an average of 44 months. Most lesions were permanent and progressive and only 6\% experienced regression. An estimated $80 \%$ of dysplasias become CIS within 10 years [16].

CIN II lesions can be categorized based on the expression of p16INK4, where lesions that express high p16INK4 require immediate treatment, while those who are not can be observed. If there is no p16INK4 examination facility, all CIN II lesions must be treated. The therapeutic method used can be ablative techniques that are cold (cryotherapy) or hot (thermal ablation) or by the excision, method using loop electrodes (LLETZ) or a scalpel (cold knife conization/CKC). Meanwhile, hysterectomy is not commonly used as a therapy for CIN, so this study also obtained the lowest percentage of hysterectomy [1]. 
However, this study has several limitations. Our descriptions of results were not solely based on the diagnosis made from histopathology examination. Since our center serves as a referral center, referred cases with cytology results were also included in the study population and some of them received treatment without subsequent confirmation of diagnosis made from histopathology. Furthermore, our observation spans for a relatively short period, and, therefore, we suggest further study with a longer period of observation to better represent the study population.

\section{CONCLUSIONS}

In conclusion, cervical precancerous lesions were the most prevalent among the group of subjects who were in the third and fourth decade of life, had low education level, were obese, multiparous, had a sexual debut at a younger age, and had used IUD as contraceptive methods. Low-grade lesions were the most prevalent histologic type of precancerous lesion.

\section{DECLARATIONS}

\section{Competing of Interest}

The authors declare no potential conflicts of interest.

\section{Acknowledgment}

Not Applicable

\section{REFERENCES}

1. Basu P, Taghavi K, Hu S-Y, et al. Management of cervical premalignant lesions. Curr Probl Cancer. 2018;42(2):129-36.

2. International Agency for Research on Cancer. Indonesia [internet]. Lyon, France: IARC, 2018 [cited 2020 Feb 22]. Available from: https://gco.iarc.fr/ today/data/factsheets/populations/360-indonesiafact-sheets.pdf

3. Andrijono. Sinopsis Kanker Ginekologi. 4th ed. Jakarta: Balai penerbit Fakultas Kedokteran Universitas Indonesia; 2013. pp 59-129.

4. Glenn McCluggage W. Premalignant lesions of the lower female genital tract: cervix, vagina and vulva. Pathology. 2013;45(3):214-28.
5. Okwi AL. Prevalence of cancerous and pre-malignant lesions of cervical cancer and their association with risk factors as seen among women in the regions of uganda. J Blood Disord Transfus. 2017;8(2) (Suppl).

6. Makuza JD, Nsanzimana S, Muhimpundu MA, et al. Prevalence and risk factors for cervical cancer and precancerous lesions in Rwanda. Pan Afr Med J. 2015;22:26.

7. Das CM, Shah N, Ghori A, et al. Prevalence and risk factors for cervical intraepithelial neoplasia in patients attending gynecological outpatient department of tertiary care hospital. J Liaquat Uni Med Health Sci. 2013;12(1):44-8.

8. Utoo B, Utoo P, Ngwan S, et al. Cervical intraepithelial neoplasia: Prevalence, risk factors, and utilization of screening services among an urban population in Nigeria. Trop J Obstet and Gynaecol. 2016;33(3):279-83.

9. Ryser MD, Rositch A, Gravitt PE. Modeling of us human papillomavirus (hpv) seroprevalence by age and sexual behavior indicates an increasing trend of hpv infection following the sexual revolution. J Infect Dis. 2017;216(5):604-11.

10. Sierra-Torres $\mathrm{CH}$, Tyring SK, Au WW. Risk contribution of sexual behavior and cigarette smoking to cervical neoplasia. Int J Gynecol Cancer. 2003;13(5):617-25.

11. Teame H, Addissie A, Ayele $W$, et al. Factors associated with cervical precancerous lesions among women screened for cervical cancer in Addis Ababa, Ethiopia: A case control study. PLOS ONE. 2018;13(1):e0191506.

12. Cullati S, Charvet-Bérard Al, Perneger TV. Cancer screening in a middle-aged general population: factors associated with practices and attitudes. BMC Public Health 2009;9:118.

13. Lertcharernrit J, Sananpanichkul P, Suknikhom W, et al. Prevalence and risk assessment of cervical cancer screening by papanicolaou smear and visual inspection with acetic acid for pregnant women at a thai provincial hospital. Asian Pac J Cancer Prev. 2016;17(8):4163-7.

14. Moodley M, Moodley J, Chetty R, Herrington CS. The role of steroid contraceptive hormones in the pathogenesis of invasive cervical cancer: A review. Int J Gynecol Cancer. 2003;13(2):103-10.

15. Cortessis VK, Barrett M, Brown Wade N, et al. Intrauterine device use and cervical cancer risk: a systematic review and meta-analysis. Obstet Gynecol. 2017;130(6):1226-36.

16. Ferlay J, Soerjomataram I, Dikshit R, et al. Cancer incidence and mortality worldwide: Sources, methods and major patterns in GLOBOCAN 2012: Globocan 2012. Int J Cancer. 2015;136(5):E359-86. 